\title{
制振デバイス付き超高強度プレキャスト $\mathrm{RC}$ 構造 による 54 階建・45 階建住宅の設計・施工
}

\author{
和泉信之 ${ }^{* 1}$ - 長田眞一 $*^{* 2}$ - 梅本宗宏*3 - 寺井靖人 ${ }^{* 4}$
}

\section{1.はじめに}

最近，都心部では，数多くの超高層住宅が建設さてい る。著者らは，免震・制振工法を用いた超高強度プレキャ スト鉄筋コンクリート構造により，高品質の超高層スケ ルトン・インフィル住宅を実現する「Super HRC（スー パー・エイチアールシー) システム」を研究開発してき た。本建物は，制振システムを適用した 54 階建と 45 階 建の超高層 RC 住宅である。54階棟は 2004 年 1 月， 45 階棟は同年 5 月に上棟した（写真-1）。

本報では，本建物に採用した構工法，構造設計扔よび 施士の概要について報告する。なお，ここでは主として 54 階棟について述べることとする。

\section{2. 建物 概 要}

本計画は，54 階建住宅棟（A 棟）４5 階建住宅棟（B 棟）抢よび駐車場 2 棟から構成されている。

建物名称：Wコンフォートタワーズ

事 業 主：三菱地所，三菱商事，菱進都市開発

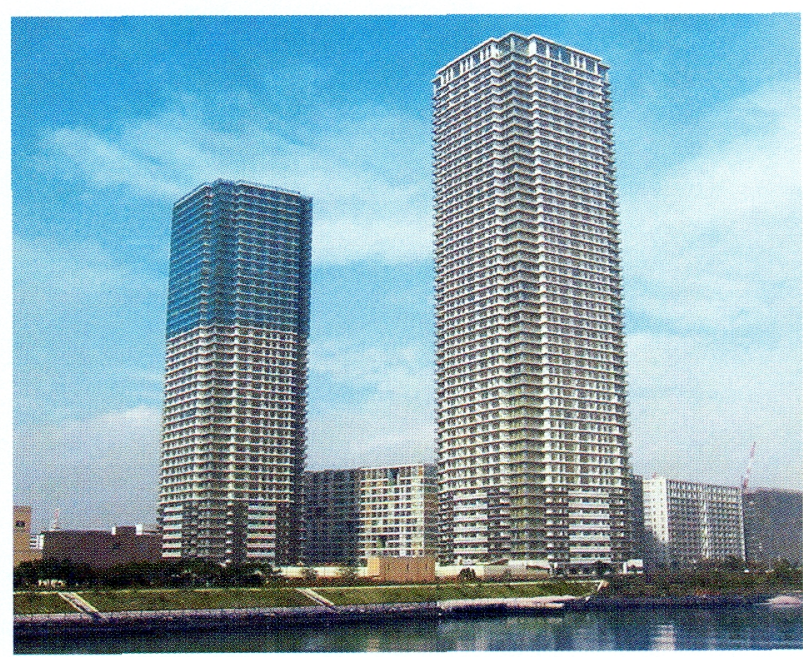

写真-1 建物全景

＊1いずみ・のぶゆき/戸田建設獭) 本社構造設計部 グループ長 (正会員)

*2 ながた・しんいち/ 今田建設㑣) 東京支店建築部 工事長

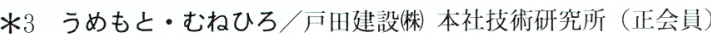

*4 てらい・やすと 户田建設㑣) 本社建築工事技術部 課長（正会 員)
設計監修監理監修：三菱地所設計

設計監理：戸田建設一級建築士事務所

施 工：戸田建設

建設場所：東京都江東区東雲 1-1-3

用途：共同住宅（住戸数 1149 戸）

建築面積: A 棟 $6700 \mathrm{~m}^{2}$ B 棟 $3655 \mathrm{~m}^{2}$

延床面積 : A 棟 $90110 \mathrm{~m}^{2}$ B 棟 $70597 \mathrm{~m}^{2}$

（面積は駐車場を含む。）

階数：A 棟地上. 54 階地下 2 階塔屋 1 階 $\mathrm{B}$ 棟地上 45 階地下 2 階塔屋 1 階

最高高さ：A 棟 $178 \mathrm{~m}$ B 棟 $153 \mathrm{~m}$

$\mathrm{A}$ 棟および $\mathrm{B}$ 棟の平面形状および立面形状は整形で ある。 $\mathrm{A}$ 棟の基準階平面（図-1）は，約 $47 \mathrm{~m}$ 角のほぼ 正方形であり，中央に吹き抜け部を有している。北側お よび吹き抜け部に階段，エレベーターなどがあり，コの 字型に住宅ゾーンが設けられている。B棟の平面は $\mathrm{A}$ 棟とほぼ同様であるが，南北方向の幅が 1 スパン分小さ い長方形である。基準階の階高は $3.2 \mathrm{~m}$ であり，塔状 比は $\mathrm{A}$ 棟が 3.7 , B 棟が 3.6 であり，両棟之も 4 以下で ある。

\section{3. 構 造 概 要}

\section{1 骨組・床形式}

$\mathrm{A}$ 棟および $\mathrm{B}$ 棟の構造は，制振デバイスを組み込ん だ骨組をプレキャスト複合化工法で構築する超高強度 $\mathrm{RC}$ 造である（図-2）。上部構造は居住空間の自由度を

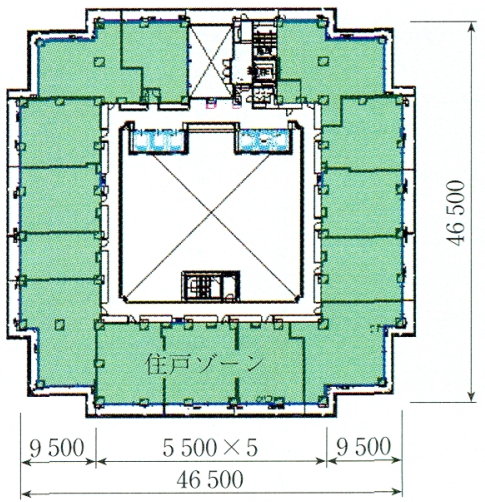

図-1Ａ 棟基準階略平面図 
高めるため, 中央の吹き抜け部を囲む剛なフレームのま わりに，開放的なフレームを束ねるように配置する骨組 形式である（図-3）。センター・フレームは, 部材断面 を増大するとともに，制振デバイス付き間柱を配置して 剛性・耐力を增している。住宅の外周部に設けたアウター・ フレームでは, 眺望性を向上させるため, 梁せいを低減 したワイド・ビームを用いている。スパン $9.5 \mathrm{~m}$, 長さ $27.5 \mathrm{~m}$ の居住ゾーンは, 住戸計画の自由度を增すため, 無柱・無梁の大型床スラブで支えている（写真-2）。大 型床スラブは, 床下配管スペースを確保し, 居室内のバ リアフリー化に対応するため, 床中央に段差を設けてい る。

\section{2 使用材料と構工法}

（1）超高強度 RC 造

コンクリートには, 設計基準強度 $\left(F_{c}\right)$ で最大 $100 \mathrm{~N} /$ $\mathrm{mm}^{2}$ ( $\mathrm{A}$ 棟 1,2 階柱）の普通コンクリートを使用して いる。主筋にはSD 295 A から USD 685 までの異形鉄 筋を，横補強筋には溶接閉鎖形式の高強度鉄筋を使用し ている(図-4)。

高強度 RC 造による骨組の構造性能は, 構造実験およ び施工実験により検証している。十字型柱梁部分骨組に よる構造実験 ${ }^{1}$ では，梁降伏型降伏機構が形成され，層 間変形角 $1 / 25$ 程度まで耐力低下のない変形性能が確認

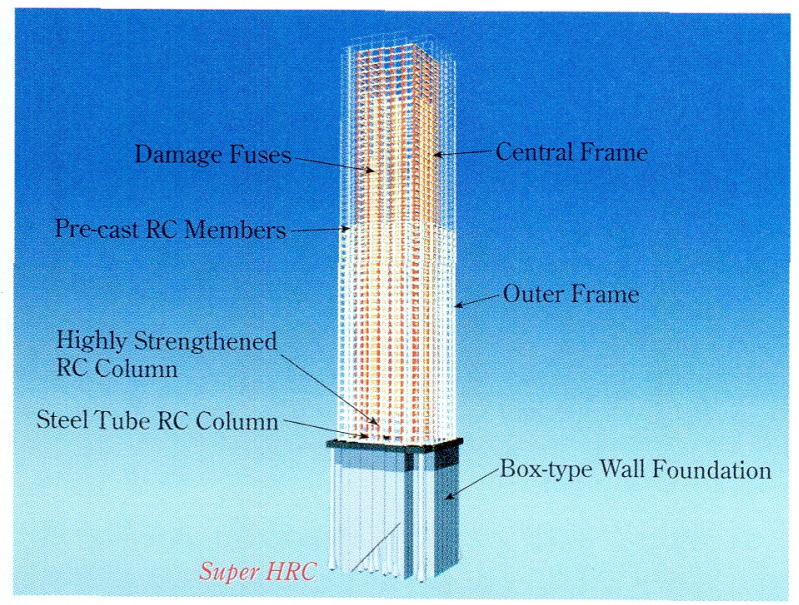

図-2＼cjkstart構造モデル概観図

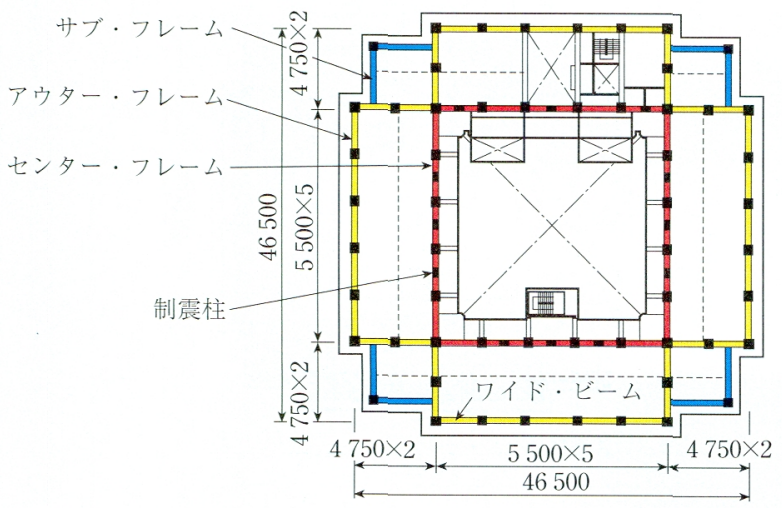

図-3 A 棟基準階略伏図
されている(図-5)。なお，図中には断面分割法による 梁曲げ終局強度を用いた降伏機構形成時の計算值を示す。 構造実験では, 大変形時の保有性能とともに，地震時の 想定変形における部材のひび割れ幅など損傷状況を確認 している。

\section{(2) 鋼管 RC 柱}

1 階の主要な柱には，A 棟では $F_{c} 100, \mathrm{~B}$ 棟では $F_{c} 80$ の普通コンクリートとUSD 685 の太径異形鉄筋を使用 し，外周鋼管と高強度帯筋でコンクリートを二重拘束し た柱（鋼管 RC 柱）である。鋼管はSS 400 であり，柱 のみを拘束して上下の RC 梁面には接しないように，あ

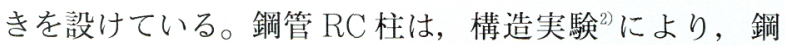
管の拘束効果により曲げ圧縮域の劣化が抑制され，部材 角 $1 / 20$ まで耐力低下のない優れた変形性能を保有する ことが確認されている（図-6）。なお，図中には断面分 割法による柱曲げ終局強度を用いた計算値を示す。

(3) 制震柱

センター・フレームには，制振デバイスとして低降伏 点鋼パネルを柱中央部に組み込んだ $\mathrm{RC}$ 造間柱（制震柱） を採用している（写真-3）。制震柱は実大試験体および 骨組試験体による水平加力実験 ${ }^{3)}$ (4) により，地震時の優

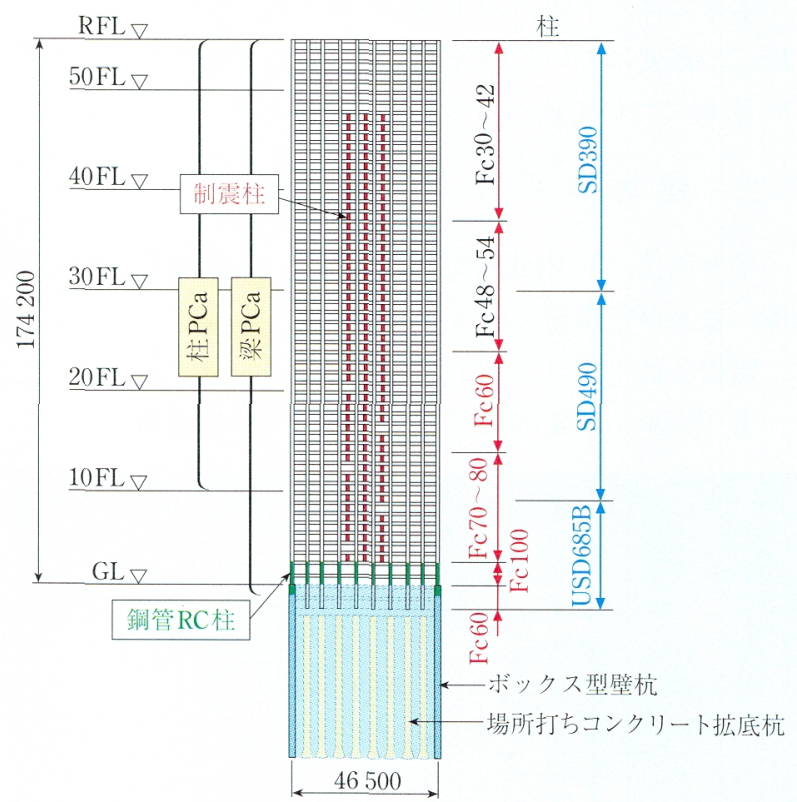

図-4＼cjkstart軸組と使用材料

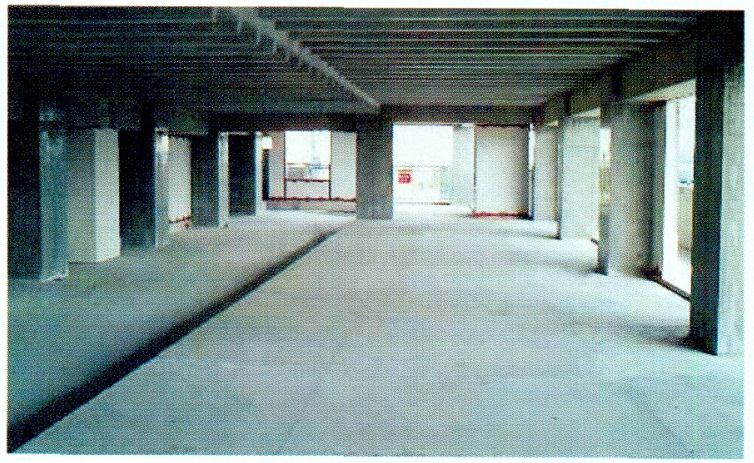

写真-2 住戸ゾーンの躯体スケルトン 

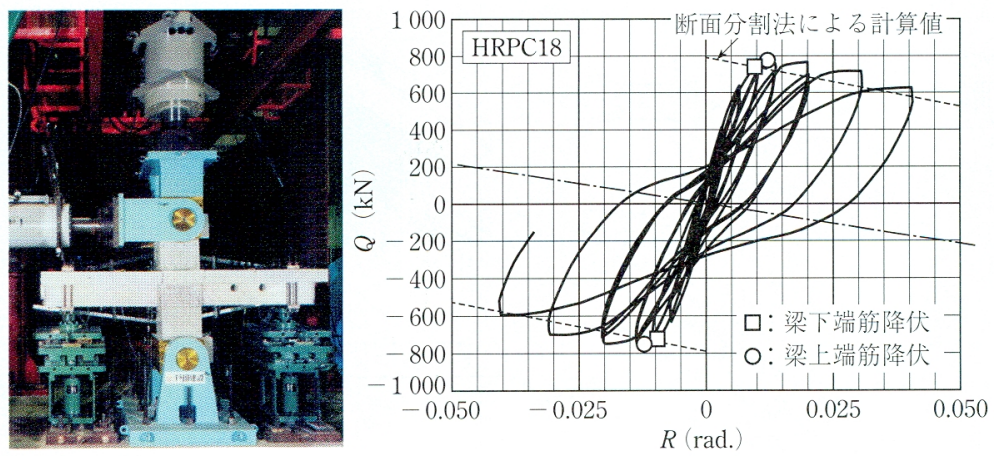

図-5＼cjkstart柱梁部分架構の荷重変形関係の例
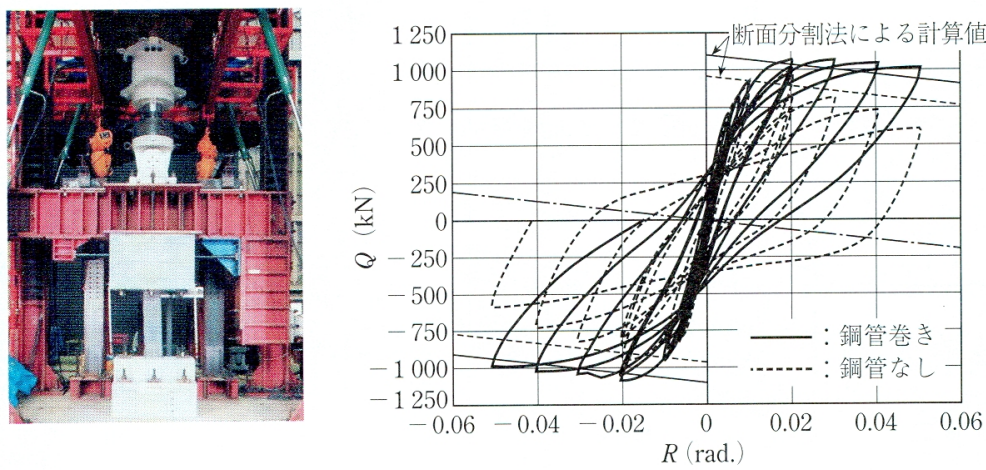

図-6 鋼管 $R C$ 柱の荷重変形関係の例
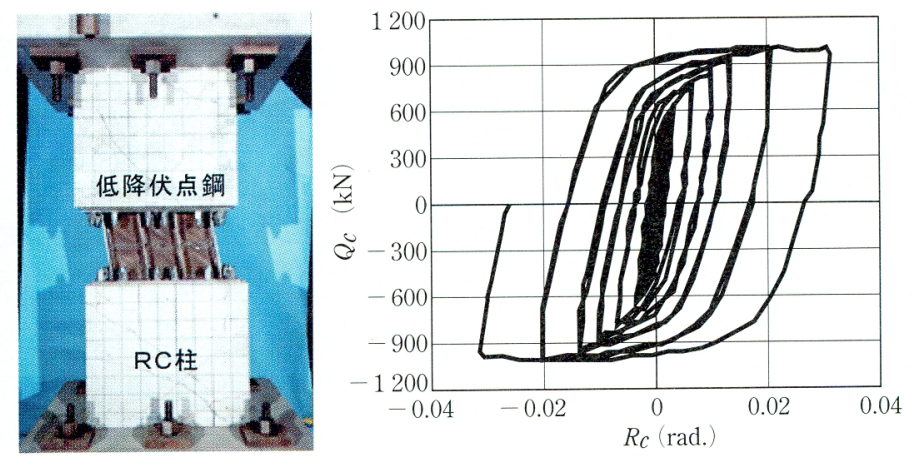

図-7 制震柱の荷重変形関係の例

れたエネルギー吸収能力を検証している（図-7）。

（4）プレキャスト複合化工法

$\mathrm{RC}$ 造の品質確保および工期短縮のため, プレキャス 卜複合化工法を採用している。本工法は，プレキャスト 部材（PCa 部材）を組み立て，接合部の鉄筋を接合し て現場打ちコンクリートを打ち込み，骨組を一体化して 現場打ち同等の構造性能を実現する工法である（図-8）。 柱は，床上から梁下までの柱部分を $\mathrm{PCa}$ 部材とし，主 筋継手にはスリーブ継手を使用している。梁は，部分 PCa 部材とし，主筋継手には機械式継手を使用している。

（5）大型段差スラブ

約 $9 \mathrm{~m}$ スパンの床スラブは，段差付きの大型プレス トレスト・プレキャスト合成スラブである。大型床スラ ブには，緊張力をプレテンション形式により導入したT 型のリブ付き PCa 床スラブを用いている。床スラブの 鉛直耐荷性能は, 常時荷重のほか, 施工時荷重, 上下方

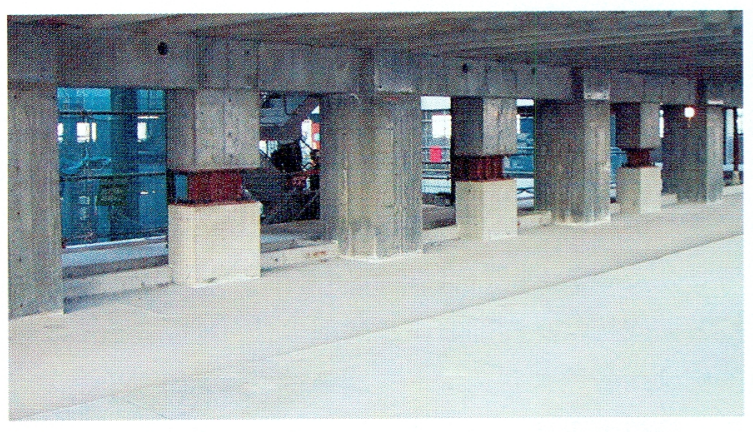

写真-3 中央ボイドまわりの制震柱

向地震力を上回る鉛直荷重に対して構造実験 ${ }^{5)}$ により検 証している（図-9）。本建物に採用した床スラブは図中 の TPS 4 試験体であり，十分な耐力抢よび変形性能を 有している。なお，段差部の補強がないTPS 2 試験体 は，設計荷重に達する前に，段差部でずれが生じて破壊 した。また，実大規模の大型段差床スラブ試験体を建設 

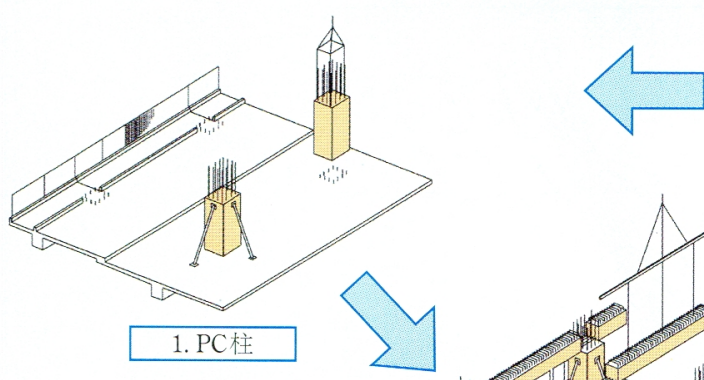

\section{西}
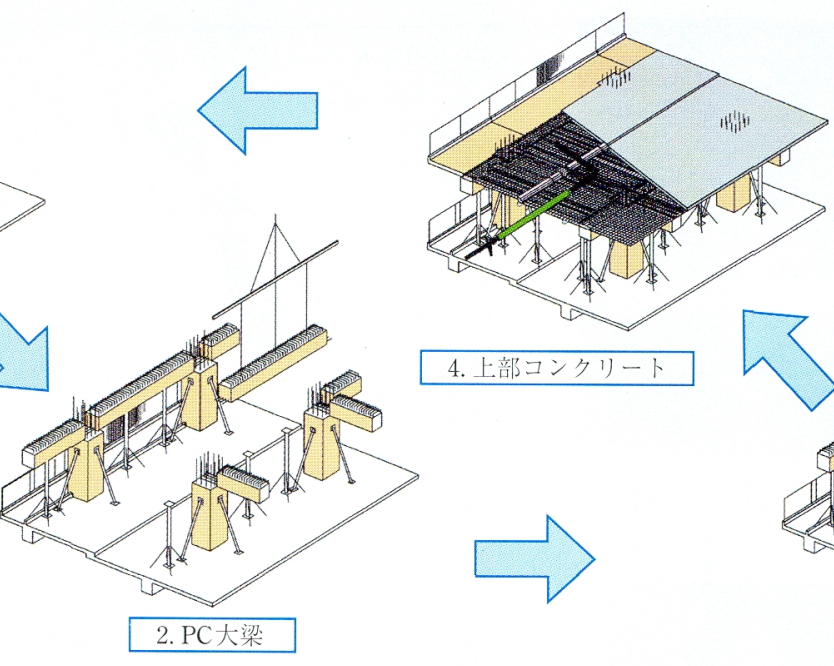

図-8＼cjkstart地上階のサイクル工程
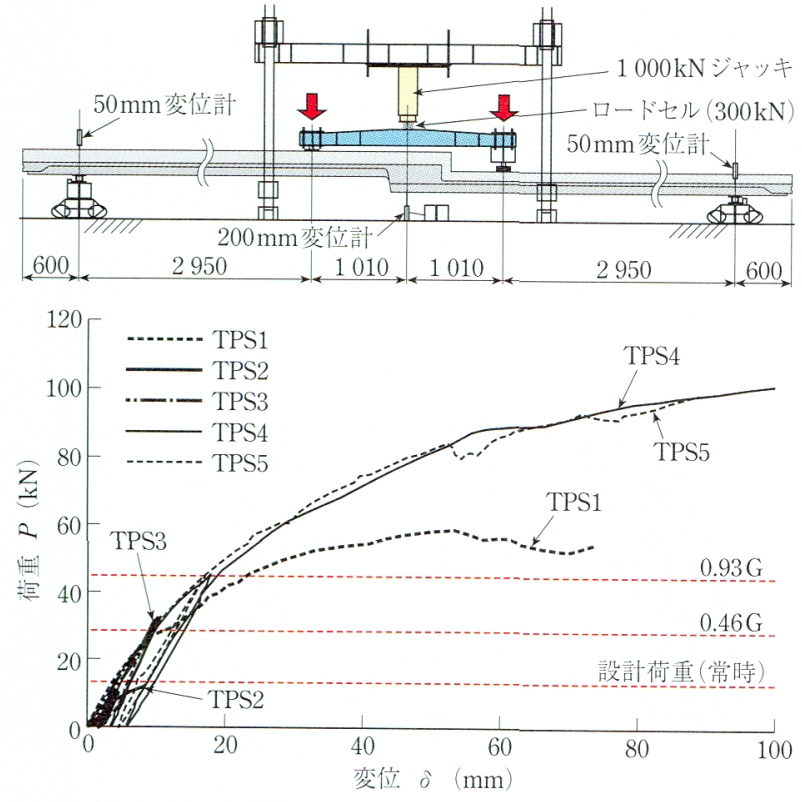

図-9 大型段差スラブの荷重変形関係の例

して，その遮音性能を検証している。

\section{3 複合杭基礎}

本敷地は, 東京湾岸地域の埋立地盤である。そのため, 基礎構造は, 地中連続壁杭 (連壁杭) と場所打ちコンク リート拡底杭（桩底杭）を併用した複合杭基礎としてい る（図-10）。杭は，深さ約 $50 \mathrm{~m}$ 以深の堅固な細砂層に 支持させている。連壁杭は，高層部直下の外周部に，場 所打ち拡底杭は，内部扔よび隅部の柱下に配置している。 連壁杭は，各壁エレメントを鋼製継手により接合されて いる。鋼製継手は, コッター筋，水平貫通筋抽よびハ二 カム鋼材を用いてエレメント間を接合する壁一壁継手で あり，地震時に壁エレメントに作用する応力を伝達する ことができる。そのため, 全体が一体のボックス型の基 礎として挙動するので, 本杭基礎は地震時に上部構造の 重量を支え，表層地盤の摇れに抵抗できる信頼性の高い 基礎構造形式である。

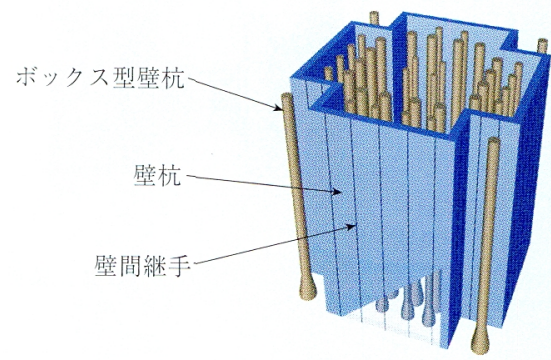

図-10 複合杭基礎の概観

\section{4. 而震設計法の概要}

\section{1 性能評価型耐震設計法}

耐震設計は，使用性，修復性および安全性について応 答值が限界值を越えないことを確認する性能評価型設計 法嘼である。設計は静的地震力に対する静的設計と設計 用地震動に対する動的設計の 2 段階である。

\section{2 限界状態と損傷制御設計}

使用性では稀に発生する可能性のある地震動（L 1 地 震動）による応答值が，修復性では極めて稀に発生する 可能性のある地震動（Ｌ２地震動）による応答值が，安 全性では建設地に発生し得る最大級の地震動（L３地震 動）による応答值がそれぞれ各限界状態を越えないこと により確保される。各限界状態は降伏状況や残留変形等 部材，または骨組に関する工学量の限界值で設定され， 具体的には表-1に示す設計判断により確認される。

梁に高強度主筋を使用するとともにスパンを大きくす ると，梁の降伏変形が大きくなるので，建物の許容変形 時における梁の塑性変形量が小さくなり，梁の残留ひび われ幅など損傷を低減することができる。例えば，層間 変形角が $1 / 100$ 程度における梁の塑性率は, 従来の超高 層 $\mathrm{RC}$ 造では 2 3 程度であるが，1〜2程度とすること が可能である。その反面，梁の履歴減衰が減少するため, 制振デバイスの減衰を付加する。さらに，制震柱による 剛性付加も加わり，地震時変形を低減し，骨組の損傷を 
表-1＼cjkstart限界状態と耐震設計判断

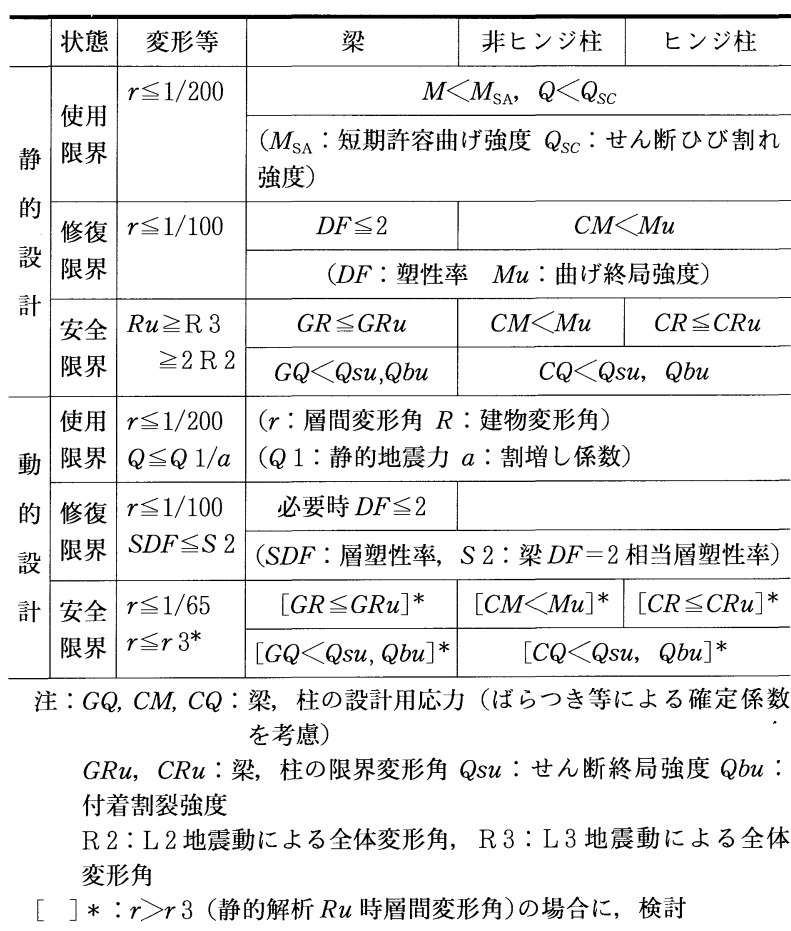

制御する設計が可能となる。

\section{3 動 的設 計}

\section{(1) 地震応答解析}

設計用地震動は，告示波，強震記録波および模擬波を 各限界状態に応じて適切に設定する。弾性 1 次固有周期 は， $\mathrm{A}$ 棟では両方向とも約 3.4 秒， B 棟では $\mathrm{X}$ 方向が 約 2.8 秒，Y 方向が約 3.0 秒である。L 1 地震動に対し て，最大応答層間変形角は，両棟とも $1 / 400$ 程度となっ ている。L 2 地震動に対して, 各層の層間変形角は約 1 $/ 130$ (B 棟)～約 1/150 (A 棟) 以下，層間せん断変形角 は約 1/140 (B 棟)～約 1/160 (A 棟) 以下である。また, 各層の最大応答層塑性率は 1.0 以下，梁塑性率は最大 1.2 程度であり，柱は制震柱を除き降伏は生じていない。

\section{（2）コンクリート強度と応答值}

超高層 $\mathrm{RC}$ 住宅の実大模擬柱のコア強度調査結果から, 構造体コンクリートの強度は，打打むね設計基準強度の 1. 2 1. 4 倍程度の範囲であることが推定される。そこ で，コンクリートの強度の増大による層の岡性等の変化 を考慮して，地震応答解析を行い，応答值の変動を検討 した。その結果, L 1 地震動では, 最大層せん断力が増 加する傾向が見られるので, 許容応力度設計用地震力を 基本剛性による応答值より大きく設定している。

(3) 制振デバイスの効果

制震柱は，層間変形角が比較的大きい中間層に設け, 上層および下層には設けていない。また，地震時の変動 軸力の上階からの累積を抑制するため，一部の階には制 震柱を設けていない（図-4）。

L 2 地震動に対する制震柱の有無による変形低減効果 を検討した。その結果，制震柱の剛性および減衰付加に より, 各階の層間変形角が均一化される傾向が見られ,
最大層間変形角は階により異なるが，20～25\%程度低減 されている。

\section{5. 施 工 概 要}

\section{1 地下連続壁杭工事}

連壁杭の厚さは A 棟では $1800 \mathrm{~mm}, \mathrm{~B}$ 棟では 1500 $\mathrm{mm}$ であり, 超高層住宅の基礎としては我が国最大級 の規模である。連壁杭の施工には, 軟弱地盤の掘削に合 理性が高く，大深度・大壁厚にも対応できるクラムシェ ルバケット型の $\mathrm{MEH}$ 掘削機を使用している。鉄筋かご は, 長さが約 $50 \mathrm{~m}$ であり, その重量は最大約 $120 \mathrm{tf}$ で ある。連壁杭のエレメントのコンクリート打設量は, 最 大約 $1100 \mathrm{~m}^{3}$ である（写真-4）。

\section{2 超高強度コンクリートの施工}

（1）超高強度コンクリートの製造および調合

$F_{c} 100$ 級の超高強度コンクリートを製造するため, 現 場に運搬可能な工場から, 高強度コンクリートの製造や 品質管理実績, 使用材料の使用条件をむとに室内実験を 行い，H工場および Y 工場の 2 工場を選定した。

H工場では, 中庸熱ポルトランドセメント（高ビー ライト系) に混和材としてシリカフューム（単位セメン 卜量の 10\%）を用いた。Y工場では，プレミックスタ イプのシリカフューム混入セメントを用いた。

${ }_{28} S_{91}$ 值は, 冬季, 夏季, 標準期の 3 シーズンの模擬 部材製造実験（図-11）を行い，各工場とも通年で同じ 值を採用した。 ${ }_{28} S_{91}$ 值は, 標準養生した供試体の材齢 28 日における圧縮強度と構造体コンクリートの材齢 91 日に打ける圧縮強度との差によるコンクリート強度の補 正值である。強度別の調合一覧を表-2 に示す。

（2）鋼管 RC 柱の施工実験

プラント実機による試し練りを実施し, 性状を確認し た後, 鋼管 $\mathrm{RC}$ 柱の施工実験を行い, $F_{c} 100$ および $F_{c} 80$ のコンクリートの打設方法を確認した。打設時には, コ ンクリートヘッドが $60 \mathrm{~cm}$ 程度上がるごとに, 約 15 秒 間バイブレータで締め固めた。また, 柱の天端には, 突 起付きシートを置いて養生した。

（3）超高強度コンクリートの品質管理結果

$F_{c} 100$ 級の超高強度コンクリートは, 2002 年 11 月か ら 2003 年 3 月の間に打設した。荷卸し時のフレッシュ コンクリートの品質を表-3 に示す。スランプフロー試 験結果は, 平均值が目標值とほぼ同等の值であり, 測定 值の多くが $65 \pm 5 \mathrm{~cm}$ の範囲内にあり, 安定していた。 $F_{c} 100$ のスランプフロー值は, 出荷から荷卸しの間で 5 $\mathrm{cm}$ 程度の増加が見られた。空気量の試験結果は, 出荷 時と荷卸し時で大きな変化はなく, 標準偏差も小さく安 定していた。

構造体コンクリートの圧縮強度試験結果は, 平均值で 調合強度を上回り，合格判定值を満足した（表-4）。そ の変動係数は 4\%以下であり, 極めて安定していた ${ }^{7)} 。$ 


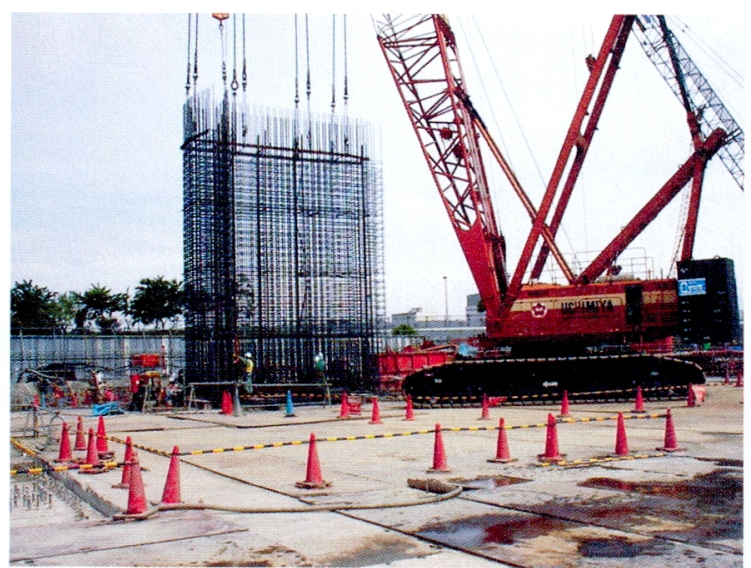

(a) 鉄筋かごの建て込み

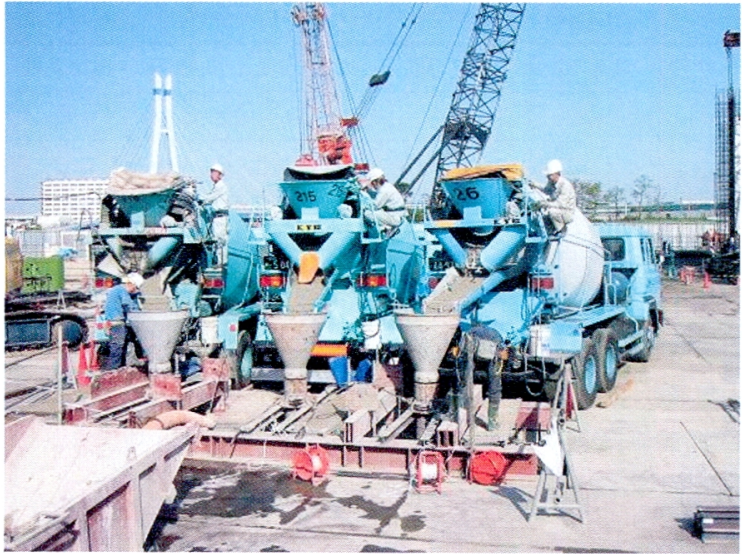

（b）コンクリートの打ち込み

写真-4 連壁杭の施工

表-2 $F_{c} 100 ・ F_{c} 80$ コンクリートの調合一覧

\begin{tabular}{|c|c|c|c|c|c|c|c|c|c|c|c|c|c|}
\hline \multirow{2}{*}{ 工 場 } & \multirow{2}{*}{$\begin{array}{c}F_{c} \\
(\mathrm{MPa})\end{array}$} & \multirow{2}{*}{$\begin{array}{l}{ }_{28} S_{91} \text { 值 } \\
\text { ( } \mathrm{MPa})\end{array}$} & \multirow{2}{*}{$\begin{array}{c}\text { 調合強度 } \\
(\mathrm{MPa})\end{array}$} & \multirow{2}{*}{$\begin{array}{c}\text { 目標スラ } \\
\text { ンプロー } \\
(\mathrm{cm})\end{array}$} & \multirow{2}{*}{$\begin{array}{l}\text { 县標 } \\
\text { 釜軍 } \\
\text { (\%) }\end{array}$} & \multirow{2}{*}{$\begin{array}{l}W / B \\
(\%)\end{array}$} & \multirow{2}{*}{$\begin{array}{l}s / a \\
(\%)\end{array}$} & \multicolumn{5}{|c|}{ 単位量 $\left(\mathrm{kg} / \mathrm{m}^{3}\right)$} & \multirow{2}{*}{$\begin{array}{l}\text { 混和剂 } \\
(C \times \%)\end{array}$} \\
\hline & & & & & & & & $W$ & C & $S F$ & $S$ & $G$ & \\
\hline \multirow{2}{*}{$\mathrm{H}$ 工場 } & 100 & 7.5 & 129 & 65 & 1.5 & 19. 0 & 44. 7 & 155 & 734 & 82 & 653 & 824 & 1. 50 \\
\hline & 80 & 7.5 & 105 & 65 & 1.5 & 24.0 & 49.5 & 155 & 581 & 65 & 793 & 824 & 1. 50 \\
\hline \multirow{2}{*}{ Y I場 } & 100 & 7.5 & 129 & 65 & 1.5 & 18. 0 & 42.5 & 155 & 862 & & 609 & 837 & 1. 40 \\
\hline & 80 & 7.5 & 105 & 65 & 1.5 & 24.0 & 49. 0 & 155 & 646 & & 791 & 837 & 1. 40 \\
\hline
\end{tabular}

$W / B$ : 水結合材比 $=W /(C+S F), s / a$ : 紐骨材率, $S F$ : シリカフューム, 混和剂の量は標準値

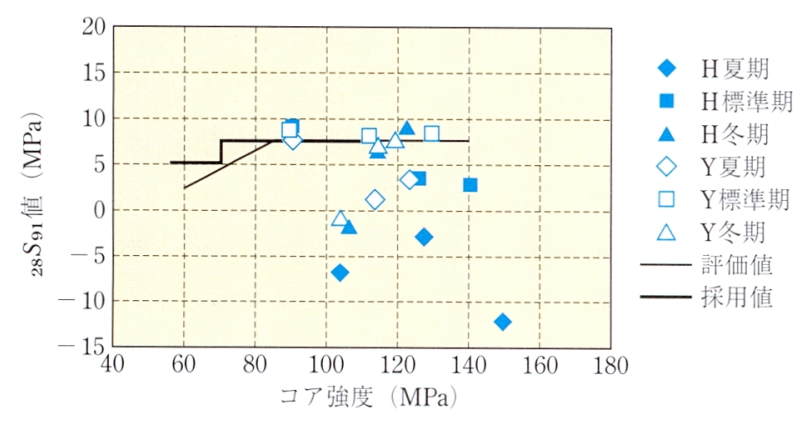

図-11 コア強度と $S$ 值

\begin{tabular}{|c|c|c|c|c|c|}
\hline \multirow{2}{*}{ 則定項目 } & 工 場 & \multicolumn{2}{|c|}{ H 工場 } & \multicolumn{2}{|c|}{ Y 工場 } \\
\hline & $F_{c}$ & $F_{c} 100$ & $F_{c} 80$ & $F_{c} 100$ & $F_{c} 80$ \\
\hline \multirow{3}{*}{$\begin{array}{l}\text { スランプ } \\
\text { フロー } \\
(\mathrm{cm})\end{array}$} & 個 数 & 40 & 116 & 55 & 91 \\
\hline & 平均 & 64.9 & 63.4 & 63.6 & 64.0 \\
\hline & 標準偏差 & 2. 98 & 3. 72 & 3. 49 & 3. 40 \\
\hline \multirow{3}{*}{$\begin{array}{c}\text { 空 気 量 } \\
(\%)\end{array}$} & 個 数 & 40 & 116 & 55 & 91 \\
\hline & 平均 & 1.5 & 1.6 & 1.8 & 1.7 \\
\hline & 標準偏差 & 0.29 & 0.30 & 0.20 & 0.25 \\
\hline
\end{tabular}

\section{3 プレキャスト複合化工法の施工}

A 棟の施工では, 現場作業量や揚重工程に配慮した 工区分けにより，基準階 1 フロアの躯体を 4 日間という 短工期で構築し (写真-5), 地上 54 階の躯体を約 15 力 月で上棟することができた。
表-4 $\boldsymbol{F}_{c} 100 ・ \boldsymbol{F}_{c} 80$ コンクリートの圧縮強度試験結果

\begin{tabular}{|c|c|c|c|c|c|}
\hline \multirow{2}{*}{ 測定項目 } & \multirow{2}{*}{$\begin{array}{c}\text { 工場 } \\
F_{c}\end{array}$} & \multicolumn{2}{|c|}{ H工場 } & \multicolumn{2}{|c|}{ Y 工場 } \\
\hline & & $F_{c} 100$ & $F_{c} 80$ & $F_{c} 100$ & $F_{c} 80$ \\
\hline \multirow{3}{*}{$\begin{array}{c}\text { 製造 時 } \\
\text { 製品検查 } \\
(\mathrm{MPa})\end{array}$} & 個 数 & 33 & 83 & 35 & 52 \\
\hline & 平均 & 135.4 & 115.8 & 135.5 & 123.0 \\
\hline & 標準偏差 & 4.5 & 5.0 & 4. 9 & 3.6 \\
\hline \multirow{3}{*}{$\begin{array}{l}\text { 構造体コ } \\
\text { ンクリー } \\
ト(\mathrm{MPa})\end{array}$} & 数 & 39 & 83 & 42 & 52 \\
\hline & 平均 & 131.2 & 114.6 & 133.6 & 121. 4 \\
\hline & 標準偏差 & 5.2 & 4.6 & 5.3 & 4.4 \\
\hline
\end{tabular}

\section{6.おわりに}

54 階建および 45 階建の超高層 RC 住宅の構工法, 耐 震設計および施工の概要について説明してきた。今後, 更なる高品質な超高層 SI 住宅を実現するため, 免震・ 制振工法による超高強度 $\mathrm{RC}$ システムを進化させていき たいと考えている。

最後に, 本計画の実現にあたりご指導・ご協力を戴い た関係各位に心から謝意を表します。

\section{参 考 文 献}

1）石川勝美・和泉信之ほか：プレキャスト鉄筋コンクリート造の柱 梁部分架構に関する実験研究（その 10～11），日本建築学会大会 学術講演梗概集, pp. 205 208, 2001 年

2）山内茂一・和泉信之ほか：超高強度材料を用いた鉄筋コンクリー 卜構造の柱部材に関する実験研究（その $3 \sim 4$ ), 日本建築学会大 会学術講演梗概集, pp.191 194, 2000 年.

3）和泉信之ほか：低降伏点鎙パネルを組み込九だ $\mathrm{RC}$ 栍の耐震性能 


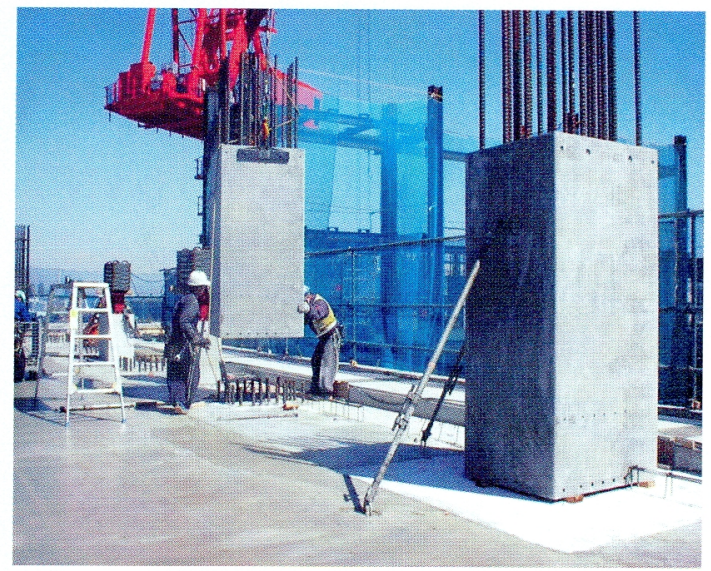

(a) $\mathrm{PCa}$ 柱の建て力

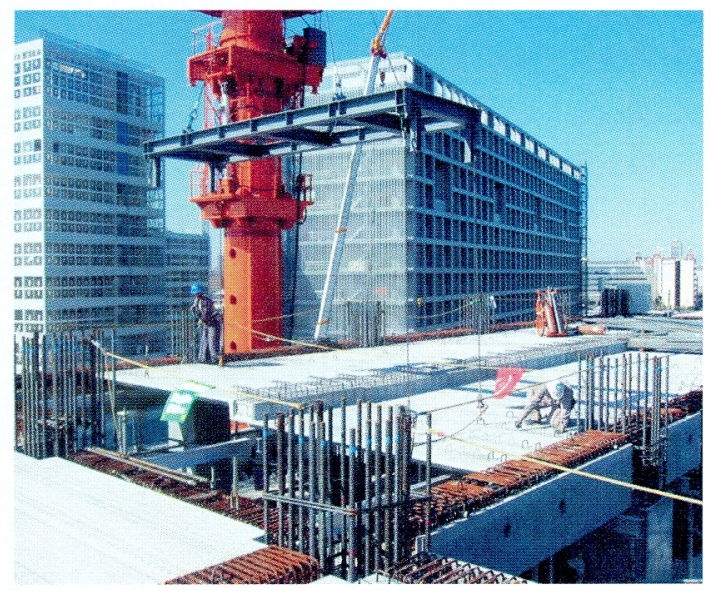

(c) 大型段差 $\mathrm{PCa}$ 床の建て方

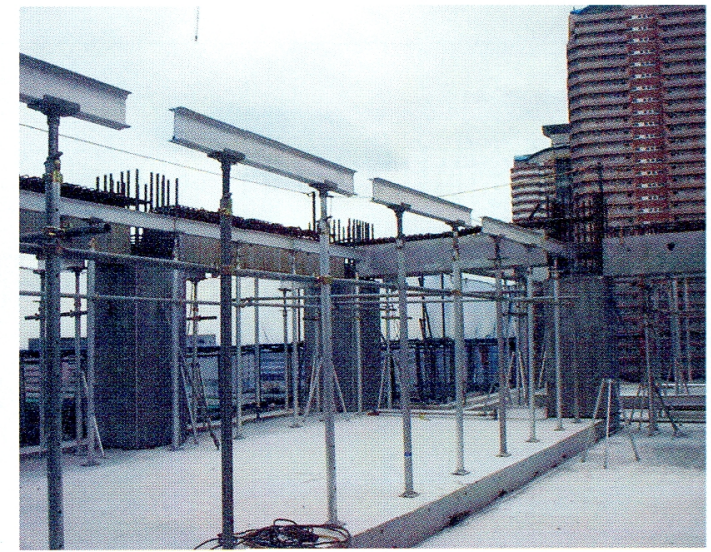

(b) $\mathrm{PCa}$ 梁の建て方

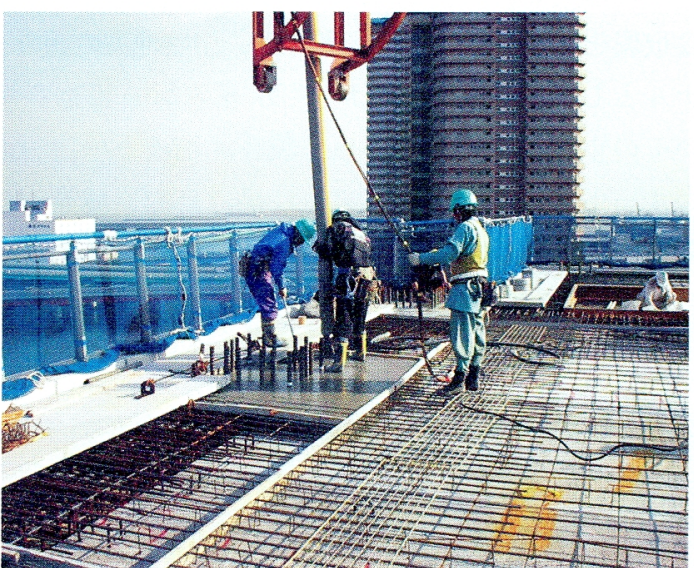

（d）上部コンクリートの打ち込み

写真 -5 躯体サイクルエ程

に関する実験的研究，コンクリート工学年次論文集, Vol.22, No.3，pp.1099 1104，2000 年

4）和泉信之ほか：制振デバイス付き $\mathrm{RC}$ 造骨組の耐震性能に関する 研究，コンクリート工学年次論文集，Vol.24，No.2, pp.1057〜 $1062 ， 2002$ 年

5）濱田 聡・和泉信之ほか：段差付き合成床スラブの耐力に関する 実験的研究, コンクリート工学年次論文集, Vol.25, No.2, pp.
673 678，2003年

6）和泉信之ほか：高性能 RC 造超高層住宅の耐震設計法（その 1〜 4), 日本建築学会大会学術講演梗概集, pp.655 662, 2001 年

7）寺井靖人ほか：超高層 RC 造集合住宅に用いた $100 \mathrm{MPa}$ 級高強 度コンクリートの品質, 日本建築学会大会学術講演梗概集, pp. 997〜998, 2003 年

《図書案内》

$$
\text { コンクリート技術の要点’04 }
$$

[本文]

1 コンクリート用材料・2 コンクリートの性質・3 コンクリートの耐久性・4 コンクリートの配（調）合設計・5 コンク

リートの製造・品質管理および検査・6 コンクリートの施工・7 コンクリート製品・8 コンクリート構造の設計

〔資料編〕

1. 新材料

B 5 判・420 ページ/定価 8400 円（税込），会員特価 7560 円（税込）／送料 400 円

-申込先：(社) 日本コンクリート工学協会・管理課「書籍販売」係

テ102-0083 東京都千代田区教町 1-7 相互半蔵門ビル 12 階／電話（03）3263-1573 